\title{
Consequential Life Cycle Assessment of Nitrogen Fertilisers Based on Biomass - a Swedish perspective
}

\author{
Serina Ahlgren ${ }^{1}$ *, Andras Baky ${ }^{2}$, Sven Bernesson ${ }^{1}$, Åke Nordberg ${ }^{1}$, Olle Norén ${ }^{2}$ and Per- \\ Anders Hansson ${ }^{1}$
}

1 Swedish University of Agricultural Sciences, Department of Energy and Technology, P.O. Box 7032, SE 75007 Uppsala, Sweden

2 Swedish Institute of Agricultural and Environmental Engineering (JTI), P.O. Box 7033, SE 75007

Uppsala, Sweden
* Author to whom correspondence should be addressed; Tel.: +46-18-671294; Fax: +46-18-673156 E-Mail: serina.ahlgren@slu.se

Received: 31 July 2012 / Accepted: 18 September 2012 / Published: 27 November 2012

\begin{abstract}
The production of mineral nitrogen represents a large fossil energy input in Swedish agriculture. However, mineral nitrogen can be produced in the Haber-Bosch synthesis, with input from renewable energy. This could lower the dependency on fossil energy and the emissions of greenhouse gases in agricultural production. The aim of this study was to investigate the land use, energy use and greenhouse gas emissions from the production of ammonium nitrate based on biomass, using consequential life cycle assessment methodology. Three scenarios are studied. In one scenario the Haber-Bosch synthesis is integrated in an existing forest residue fired combined heat and power plant. In another two scenarios thermochemical gasification of biomass in combination with HaberBosch synthesis is studied, using either straw or short rotation coppice (Salix) as raw material. The results showed that the greenhouse gas emissions and use of fossil energy can be significantly lowered. The size of emission reductions compared to using fossil fuels as raw material is dependent on choice of data, but also choice of functional unit and if e.g. indirect land use change is included. The study also showed that using green nitrogen in rapeseed production substantially can lower the carbon footprint. Further, we argue that production of nitrogen based on renewables should be a high-priority activity, as nitrogen is one of the pillars for a secure food and bioenergy supply for a growing world population.
\end{abstract}

Keywords: nitrogen; fertilisers; renewable; biomass; electrolysis; gasification; GHG; LCA; land use 


\section{Introduction:}

Nitrogen fertilisers are needed in agriculture to obtain high yields of agricultural crops. Large-scale use of mineral nitrogen fertilisers began after Second World War and without this, the expansion of the world population would have been impossible [1]. The use of nitrogen fertilisers is predicted to increase in the future due to population growth, increased consumption of meat and increased use of biofuels [2,3].

Nitrogen gas accounts for $78 \%$ of the volume of our atmosphere. However, converting it to a form that is useful for agriculture costs energy. At present, the production of nitrogen fertiliser accounts for $1.2 \%$ of global primary energy demand [4]. Production is most commonly based on natural gas, but gasification of coal and heavy oil also occurs. In the long run, this is not a sustainable solution for our food production, as fossil fuels is a finite energy source. The use of fossil fuels also contributes to global warming.

The total use of energy in Swedish agriculture is estimated to be 33 PJ per year; of this nitrogen production is ca 6.5 PJ [5]. The greenhouse gas (GHG) emissions due to the production of fertilisers accounts for $9 \%$ of the emissions from agriculture in Sweden [6]. On a global scale, the production of nitrogen fertilisers is calculated to represent about $1 \%$ of anthropogenic GHG emissions [4]. On a product level, the production of nitrogen fertilisers can have a large impact, e.g. when calculating the carbon footprint of food and biofuel. For example in a study by Börjesson and Tufvesson [7], nitrogen fertilisers were found to be between 3-26\% of the total GHG emissions from wheat based ethanol production. For rapeseed biodiesel, the nitrogen fertiliser production was up to $29 \%$ of the GHG emissions.

Ammonia is the building block for most mineral nitrogen products. All commercially produced ammonia at present uses the Haber-Bosch process, the overall reaction being: $\mathrm{N}_{2}+3 \mathrm{H}_{2} \rightarrow 2 \mathrm{NH}_{3}$. While nitrogen is supplied from ambient air, it is the production of the hydrogen that costs energy. Most commonly hydrogen is produced from natural gas, coal or heavy oils.

The energy requirement has dramatically decreased over time from about $55 \mathrm{GJ} / \mathrm{metric}$ ton of ammonia produced in the 1950 s to $35 \mathrm{GJ} /$ ton in the 1970s, while nowadays the best plants using natural gas as feedstock need only $28 \mathrm{GJ} /$ ton. The thermodynamic minimum energy requirement is 20 GJ/ton $\mathrm{NH}_{3}$ [1]. According to the International Fertilizer Industry Association about $67 \%$ of global ammonia production is based on natural gas, $27 \%$ on coal while fuel oil and naphtha account for $5 \%$ [4]. Since a number of old plants are still in operation, the global average energy requirement was in 2008 around $37 \mathrm{GJ} /$ ton ammonia (ranging from 27-58 GJ/ton $\mathrm{NH}_{3}$ ) [8].

Once ammonia is produced, it can be used to make straight nitrogen fertilisers (a straight fertiliser is defined as to contain only one primary nutrient) - or together with phosphate, potassium or micronutrients to make compound fertilisers (a compound fertiliser is defines as to contain two or more primary nutrients) [9]. In this study, production of ammonium nitrate was investigated. To produce ammonium nitrate, about half the ammonia produced is first processed to nitric acid. The nitric acid is then reacted with the remaining ammonia to produce ammonium nitrate.

The GHG emissions associated with nitrogen fertiliser production is $\mathrm{CO}_{2}$ from the carbon in the fossil fuels used. Further, in the production of nitric acid, nitrous oxide $\left(\mathrm{N}_{2} \mathrm{O}\right)$ is generated. In recent years, catalytic filters have been installed in a number of plants to remove the nitrous oxides. This can greatly reduce the GHG emissions from ammonium nitrate production. 
The hydrogen needed for ammonia production in the Haber-Bosch synthesis can also be produced from renewable resources. This opens up for a more sustainable production of food, feed, fibres and fuels. There are four main options available for the production of renewable hydrogen [10, 11]: (1) electrolysis based on renewable electricity; (2) reforming of biogas; (3) thermal conversion of biomass (e.g. pyrolysis and gasification) and (4) collection of hydrogen produced by algae and photosynthesising organisms.

In this study, electrolysis (1) and thermal gasification (3) were studied. Electrolysis is the process by which water is split into hydrogen and oxygen with the aid of electricity. Thermal gasification (partial oxidation) means that the biomass is combusted, but with a shortage of oxidant (air, oxygen and/or steam). Instead of producing heat as in normal combustion, the product is an energy-rich gas. While technology for hydrogen production via electrolysis is well established, the biomass gasification is on a still on a demo level [12]. Production of hydrogen by reforming of biogas (2) and thermal gasification (3) and thereafter synthesis to nitrogen fertilisers has been studied by [13, 14]. Collection of hydrogen produced by algae etc. (4) is so far only at laboratory-scale.

There have been some production facilities utilising electrolysis to produce ammonia. In the 1940s and 1950s, several small-scale electrolytic ammonia plants were built in for example Norway, Egypt, Peru, Iceland and Zimbabwe. However, most of these have been decommissioned [15]. Between 1948 and 1990, the company Norsk Hydro operated a hydropower-driven electrolyser with 150 MW capacity, the hydrogen being used to produce ammonia. During the oil crisis in the 1970s and 1980s, production of ammonia on a small scale was considered as a way of reducing the dependency on fossil oil. Some techno-economic studies were carried out on electrolysis-based ammonia production, see for example Dubey [16], Jourdan and Roguenant, [17] and Grundt and Christiansen [18].

At present, the ammonia production based on renewables is becoming interesting again, as a measure to reduce fossil fuel dependency and to reduce GHG emissions. In Minnesota, USA, a plant is currently being commissioned that will produce 1 ton per day ammonia in a Haber-Bosch synthesis reactor, the hydrogen needed for the synthesis is derived from wind-powered electrolysis [19].

The aim of this study was to investigate the land use, energy use and GHG emissions from the production of ammonium nitrate based on biomass. Two technologies are studied, in three different scenarios. In one scenario ammonium nitrate production is integrated in an existing forest residues fired combined heat and power (CHP) where the electricity is used to drive an electrolyser, producing the required hydrogen for the ammonia synthesis. In another two scenarios, dedicated plants for nitrogen production was investigated assuming thermochemical gasification of biomass for hydrogen production, using either straw or short rotation coppice (Salix, i.e. willow) as raw material. Ammonium nitrate was chosen since it is the most commonly used nitrogen fertiliser in Sweden.

\section{Method}

The method used to evaluate the systems in the study was life cycle assessment (LCA). LCA is a methodology used for studying the potential impact on the environment caused by a chosen product, service or system. The amount of energy needed to produce the specific product and the environmental impact are calculated. The life cycle assessment is limited by its outer system boundaries. The energy and material flows across the boundaries are looked upon as inputs (resources) and outputs (emissions) [20]. A distinction can be made between two types of LCA. Attributional LCA study accounts the 
flows to and from a studied system but do not consider effects outside the system boundary. Consequential LCA, which is applied in this study, describes how flows will change in response to a possible decision and includes effects both inside and outside the life cycle of the studied system.

The consequential LCA take into account changes of a system by studying market reactions. A very important step in a consequential LCA study is to identify which marginal market changes takes place. This can often be decisive for the outcome of the study. However, identifying the marginal production can be a rather complicated task.

First of all, it is important to distinguish between short-term and long-term marginal changes. Shortterm marginal production is the last unit to be taken into production when demand increases and will be the unit with the highest operation costs. The long-term marginal production involves changes in capacity, i.e. instalment of new plants as a response to a change in demand [21]. Further, the geographical location is also important for the choice of marginal data. For example, in certain locations there are physical limitations to market exchange, e.g. when heat production or consumption is involved, or when bottlenecks exist in the electricity transmission system [22]. Additionally, regulatory systems can distort the market and have an influence on the marginal production. As Finnveden [23] points out, introducing $\mathrm{CO} 2$ caps in the EU electricity market could lead to a renewable fuel being on the margin, or more likely a complex mix of different types of energy sources.

A number of methods and energy prediction models are available to establish the marginal energy production, but it tends to be very difficult to reflect the effects in a proper way and the results are therefore highly uncertain [22]. It can also be done in a more simplistic way by assuming a single marginal technology. In a review of consequential LCA studies, Mathiesen et al. [22] found that most studies identified coal CHP as the marginal production for electricity, whereas the results for heat were more varied. In the majority of the studies reviewed, a long-term time horizon of 10-20 years was used. The choice of marginal production for this study is further treated in chapter 3.

The energy balance is calculated as primary energy (Table 1). The characterisation factors for global warming were chosen for a 100-year perspective; fossil $\mathrm{CO}_{2}: 1, \mathrm{CH}_{4}: 25$ and $\mathrm{N}_{2} \mathrm{O}: 298$ (IPCC, 2007). $\mathrm{CO}_{2}$ from biomass was assumed to not contribute to global warming, with the argument that the $\mathrm{CO}_{2}$ released at combustion has recently been captured by the biomass in question. While this at present is standard procedure in LCA, there is also an emerging discussion that the time lag between capture and release of $\mathrm{CO}_{2}$ inherent to perennial bioenergy must be considered (see e.g. [24]). The methodology is however far from settled and was not included in the present study.

Table 1. Primary energy factors used in the study [25]

\begin{tabular}{lll}
\hline Energy source & Factor & Comment \\
\hline Diesel & 1.06 & Factor for production and distribution \\
\hline Natural gas & 1.06 & Factor for production and distribution \\
\hline District heating (oil) & 1.27 & Factor for production, distribution and conversion losses \\
\hline Electricity (coal) & 2.72 & Factor for production, distribution and conversion losses \\
\hline
\end{tabular}


The land use is expressed as the number of hectares needed per functional unit (FU). It also important to account for any changes in the soil carbon content in the GHG balance. Therefore the former use of the land must be established. Quantifying emissions connected to loss or accumulation of carbon at the site of cultivation of the raw material can be referred to as the direct land use change (DLUC). In recent years, however, there have been discussions to also include indirect land use change (ILUC) in LCA. If the land used for energy crops was previously used for other activities, for example cereal production or pasture, it is probable that the demand for these products will still continue to exist. The demand for the products previously produced from the land now occupied by energy crops can be met by increasing the yields on the same land, or by moving the activities to another location. This moving of activities can cause land use changes, for example by utilisation of previously uncultivated land within the country under study or outside that country [26]. However, ILUC can not be observed, quantification requires the use of e.g. economic equilibrium models and the results are associated with high uncertainty. While DLUC is included in the base case of this study, ILUC is further treated in the sensitivity analysis.

The functional unit in this study was set to the production of 1 metric ton of fertiliser nitrogen based on renewable resources as ammonium nitrate $(33.5 \% \mathrm{~N})$ at the gate of the production facility, assuming that the nitrogen produced avoids the production of a fossil fuel-based alternative.

\section{System description}

In scenario 1, nitrogen fertiliser production integrated into an existing CHP plant is studied. At present, forest residues is the main biomass used in Swedish CHPs [27]. The electricity previously sold to the grid is now used for fertiliser production. This means that the electricity no longer put on the grid must be produced elsewhere (Figure 1). In scenario 2 (straw) and 3 (Salix), a new plant utilising thermal gasification technology to produce hydrogen for fertiliser production is studied. Straw and Salix has been pointed out as promising future possible biomass energy sources, especially in combination with gasification technology [28]. The "green fertilisers" produced were assumed to replace the use of other types of marginal nitrogen.

As previously mentioned, the choice of replaced marginal production is vital for consequential LCA studies and closely connected to the choice of geographical scope. In the case at hand, we study use of Swedish raw material for production of nitrogen fertilisers in Sweden. The geographical scope is therefore set to Sweden. Next step is then to identify the marginal production in Sweden, of heat, electricity and nitrogen fertilisers. In this study we apply a simplified reasoning of the marginal production, to identify the short-term marginal.

The electricity market in Sweden is integrated together with the other Nordic countries (Denmark, Finland and Norway). Besides the Nordic countries, Sweden is able to import and export electricity from Germany and Poland; two countries that are highly dependent on coal fired power generation (in Poland $89 \%$ of all electricity was coal condensation power in 2008; in Germany $46 \%$ ). Import from these countries only happens when all other alternatives have been exhausted and as backup power [29]. We therefore assumed coal power as the marginal technology for electricity.

The local district heating networks are well developed and are available in more than 270 out of Sweden's 290 municipalities. The fuel mix has transitioned from primarily fossil to nowadays being 
mainly bio-based. The peak heating load is however often natural gas or oil [29]. Based on this, we assumed that fossil oil is the marginal production for district heating.

There is no production of nitrogen fertilisers in Sweden, but all is imported. However we found no studies or statistics on the origin of the imports. The European nitrogen industry is about to be included in the EU emission trading system, making it costly for them to emit greenhouse gases. Therefore the marginal production was assumed to be an older natural gas plant without nitrous oxide removal, with emissions of $7.3 \mathrm{~kg} \mathrm{CO}_{2}$-eq $/ \mathrm{kg} \mathrm{N}$, based on data in [4].

To highlight the uncertainty in assumptions of marginal production, Finnveden [23] recommends that two scenarios be used in LCAs, one high $\mathrm{CO}_{2}$ emission marginal alternative and one with low $\mathrm{CO}_{2}$ emissions. In this study a low $\mathrm{CO}_{2}$ emissions scenario is applied in the sensitivity analysis.

In all scenarios, a net production of 165 ton $\mathrm{N}$ per year of ammonium nitrate was modelled. Most new nitrogen fertilisers built today based on natural gas are much larger; 1000-1500 ton ammonia per day is common, with up to 5000 ton per day [30,31]. The large scale of the ammonia facilities is not so much because of technical constraints but due to economies of scale. The technical details in the scenarios are further described in [32].

Figure 1. Visual description of the studied scenarios.

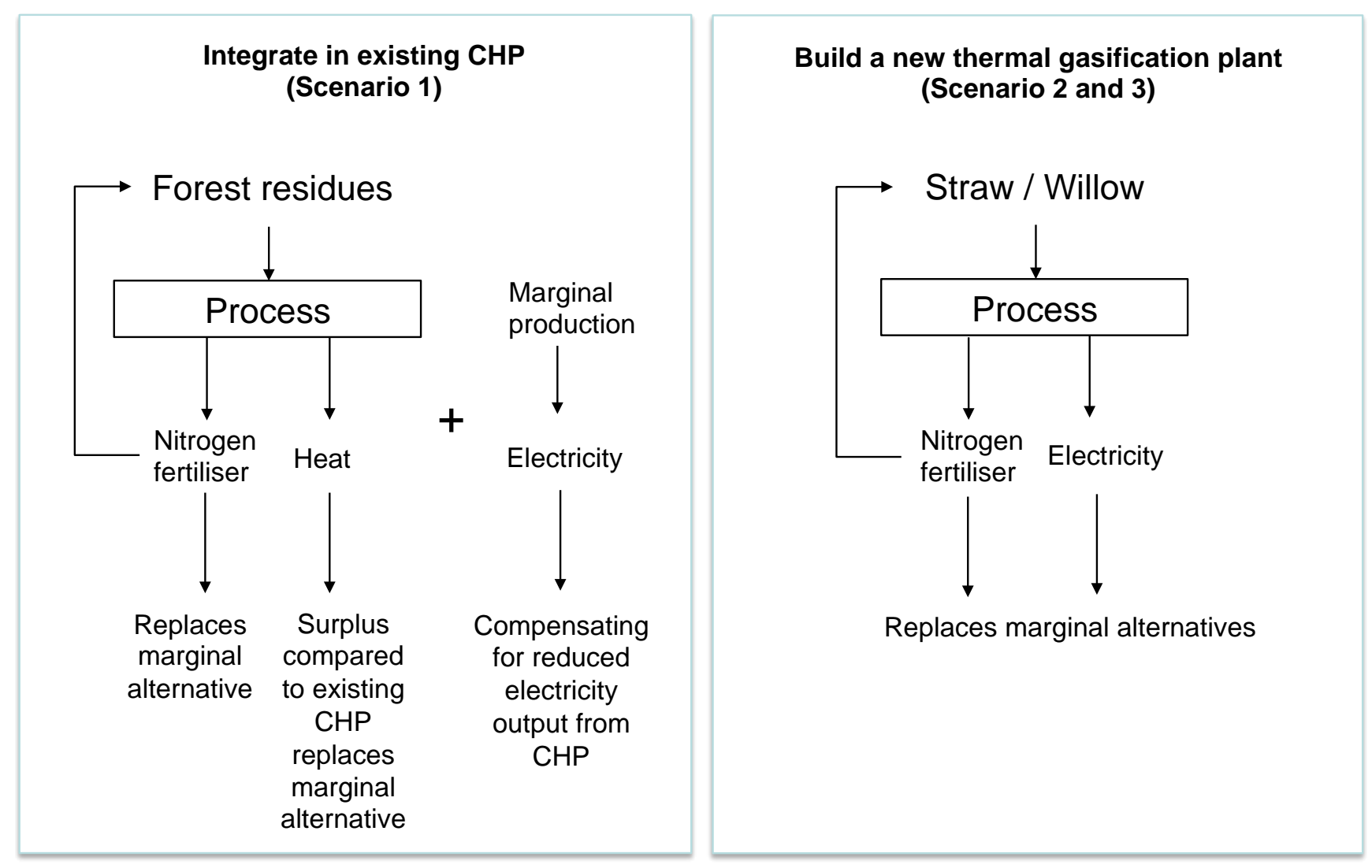




\subsection{System boundaries and delimitations}

The raw material was assumed to be of Swedish origin. The emissions of GHG were quantified from 'cradle-to-gate', i.e. all the emissions stemming from raw material acquisition to ammonium nitrate product at the factory gate were included. The use of the produced fertiliser was therefore not included. However, fertilisers are needed in cultivation. Therefore it was assumed that part of the ammonium nitrate produced is returned to the plantation/field (Figure 1). For willow (Salix) plantations, the amount of returned nitrogen was according to the fertiliser recommendations [33], while for straw and forest residues the amount of returned nitrogen was calculated as the amount of nitrogen removed with the straw/residue [34]. The emissions arising from the use of those fertilisers (mainly nitrous oxide from soil) were included in the calculations.

Furthermore, bottom ash from combustion and gasification, which contains valuable phosphorus and potassium, was assumed to be returned to the growing site. The return of ash to agricultural fields is not regulated by Swedish law. However, there are regulations for spreading of sewage sludge, which could serve as guidelines for upper limit of heavy metals [35].

In the electrolysis process, water is split to produce hydrogen. As a by-product, oxygen is formed. In the air separation unit used in the gasification scenarios to produce nitrogen, oxygen is also formed as a by-product. The oxygen can be sold to other industries, but it is not certain that there is a market for this, so it was not given any value in this study.

Emissions from production of capital goods such as machinery and buildings were not included in the bioenergy calculations, since in previous studies they have been found to have little impact on the results when converting biomass to fuel (or, as in this case, to nitrogen) [36, 37].

\subsection{Cultivation/collection of biomass raw material}

The yield of straw was calculated to 4.3 ton dry matter per hectare and year, based on the 5-year average of winter wheat yield (2005-2010) [38] and multiplied by a straw harvest factor of 0.85 [39]. Data on the energy use for windrowing, baling and collection were taken from Nilsson [40]. For Salix, a yield of 10 ton dry matter per hectare and year was assumed. Data on energy use for planting, weed control, harvest etc. were taken from Börjesson [41]. For forest residues, it was assumed that 32 wet ton of residues per hectare are collected after final felling [42]. This is an average yield after final felling of a mix of rich and poor spruce and pine stands. With a rotation time of 80 years, this on average gives $217 \mathrm{~kg}$ dry matter per hectare and year. Data on energy for collecting, bundling etc. were taken from Lindholm [43].

\subsection{Land use and soil carbon}

In scenario 1, forest residues are used as the raw material for nitrogen fertiliser production. Harvesting forest residues leads to no actual land use as it is a by-product from forestry. This is under the assumption that the residues previously are not utilised for any other purpose and therefore has no indirect effects on land use. However, forest residues contain some carbon that would have been left in the forest if not utilised. In a study by Lindholm [43], the effect on the soil carbon content when removing forest residues was analysed using a model and proved to be very dependent on the time frame assumed. Over a long time period (2-3 rotations or 240 years) the decrease in soil $\mathrm{C}$ was 
calculated to between 2.9 and $3.5 \mathrm{~kg} \mathrm{C} / \mathrm{ha}$ and year when removing logging residues after the final fellings. Other studies have found higher decreases, $17-50 \mathrm{~kg} \mathrm{C} / \mathrm{ha}$ and year (see review of other studies in [43]). In the present study an average loss of $3.2 \mathrm{~kg}$ soil $\mathrm{C} / \mathrm{ha}$ and year was assumed in the base case scenario over a longer time period (2-3 rotations). This means that the time frame for soil carbon changes is different for the forest residue scenario compared to the straw and Salix scenarios.

In scenarios 2, straw was assumed to be used as raw material. Similar to the forest residues, harvesting straw leads to no actual land use as it is a by-product from cereal cultivation. This is under the assumption that the straw is previously not utilised for any other purpose and therefore has no indirect effects on land use. There are no recent surveys of straw utilisation in Sweden, the latest one dating from 1997. In that, it was estimated that $1 \%$ of the straw was burned on field, $64 \%$ incorporated in soil and 35\% harvested (utilised as feed, litter and energy) [44]. Here we assume that there is enough straw available for harvesting that is currently not utilised.

However, harvesting straw can have an impact on the soil carbon content. Straw incorporated into soil will decompose, but part will be transferred to the long-term soil carbon pool. The rate of decomposition and transfer to long-term carbon pool depends on many factors, such as the characteristics of the soil (e.g. structure, $\mathrm{pH}$, initial carbon) and climate (e.g. temperature, humidity) and farming practices (e.g. rotation, tillage) [45].

Trials with radioactive labelling in Sweden show that only 5-10\% of incorporated carbon in straw is left in the soil after 10-20 years [46]. Assuming a straw harvest of 4 ton and a carbon content of 50\% results in between 200 and $400 \mathrm{~kg} \mathrm{C}$ left after 10-20 years. Assuming a longer time perspective would reduce the amount of carbon left. In a study by Johansson [45], a model for soil carbon with and without straw removal showed a difference of $5300 \mathrm{~kg} \mathrm{C}$ per hectare and year after 100 years $(53 \mathrm{~kg} \mathrm{C}$ difference per year on average). In a long-term field trial in Sweden [47], removal of straw showed no impact on topsoil C. In yet another study modelling soil C removal, a variation of $78-385 \mathrm{~kg} \mathrm{C} / \mathrm{ha}$ and year was observed [48].

In conclusion, the effect of straw harvest on soil $\mathrm{C}$ is difficult to assess and is dependent on local factors and the time period studied. In this study we assumed that removing straw results in a reduction of $150 \mathrm{~kg} \mathrm{C} / \mathrm{ha}$ and year, over a period of about 30-50 years after which the soil carbon level will have reached a new steady state [7].

In scenarios 3, willow (Salix) was assumed to be used as raw material. At present, only 13000 ha of Salix are planted in Sweden [49]. However, the potential is reported to be as large as 200000 ha [28]. In 2010, about $6.7 \%$ (equal to 176800 ha) of Swedish farm land is under fallow [49]. There is also a great deal of abandoned farmland; the cultivated area has declined by about 300000 hectares since the 1970s [28]. According to a study by the Swedish Board of Agriculture, there is also an overproduction of 200 000-300 000 hectares of ley which is not utilised [50]. It is reasonable to believe that increased planting of Salix will take place on all these different types of land..It is difficult to foresee how land use will develop on Sweden, but we assume that at least the reported potential of 200000 hectares of land can be utilised for Salix planation without any indirect land use changes. Salix is a perennial crop with a large root system. Planting Salix will therefore often have a positive effect on soil carbon content. A combination of different previous land uses was assumed here (Table 2). 
Table 2. Soil carbon change when Salix is planted on different types of land and the assumed share of each land type converted

\begin{tabular}{lll}
\hline Type of land & $\begin{array}{l}\text { Soil carbon change } \\
\text { (kg C/ha year) }\end{array}$ & $\begin{array}{l}\text { Assumed share of land } \\
\text { used to plant Salix }\end{array}$ \\
\hline Fallow farm land (mineral soil) & $+500^{1}$ & $50 \%$ \\
Fallow farm land (organic soil) & $+1700^{2}$ & $5 \%$ \\
Previously ley & $0^{1}$ & $25 \%$ \\
Abandoned farm land & $0^{3}$ & $20 \%$ \\
\hline
\end{tabular}

${ }^{1}$ Ref: Börjesson (1999)

${ }^{2}$ Ref: Berglund and Berglund (2010)

${ }^{3}$ The quality of abandoned farm land varies, which makes it difficult to assess the effect of cultivating Salix. We assumed that on average, there is no change in soil carbon.

The average soil carbon stock change for planting Salix in Sweden was calculated to be an average increase of $335 \mathrm{~kg} \mathrm{C} / \mathrm{ha}$ and year $\left(1228 \mathrm{~kg} \mathrm{CO}_{2}\right.$-eq/ha and year) based on data in Table 2. This is assumed over a period of about 30-50 years after which the soil carbon level will have reached a new steady state. Similar to straw removal, the uncertainty in carbon stock changes due to Salix plantation is very large and great variations are reported in the literature. Therefore this issue is further dealt with in the sensitivity analysis.

\subsection{Transport of biomass raw material}

The transport distance for biomass was calculated using the model described in [51] and [52]. According to this, the area from which biomass is collected was assumed to be circular, with the plant in the centre. The average transportation distance is dependent on the biomass requirements of the production plant, a road tortuosity factor and the available amount of biomass in the area. The transport distance was estimated to be 100,70 and $44 \mathrm{~km}$ respectively in scenario 1, 2 and 3 .

\subsection{Nitrogen fertiliser production}

In scenario 1, solid oxide high temperature electrolysis was assumed for the hydrogen production, utilising electricity $\left(120 \mathrm{MJ} / \mathrm{kg} \mathrm{H}_{2}\right)$ and steam $\left(28 \mathrm{MJ} / \mathrm{kg} \mathrm{H}_{2}\right)$, data collected from Zeng and Zhang [53]. For the thermochemical conversion route, the hydrogen yield and electricity requirement were based on data found in Hamelinck and Faaij [54] and emissions data from Edwards et al. [55].

The hydrogen is together with nitrogen gas synthesised to ammonia. The nitrogen gas was assumed to be produced in a cryogenic air separation plant. The synthesis of ammonia typically takes place over an iron catalyst at pressures of around $100-250$ bar and temperature $350-550^{\circ} \mathrm{C}$. The conversion efficiency to ammonia is low because of thermodynamic restrictions (20-30\%) and the unreacted gas is recirculated. The ammonia that is formed is separated from the recycled gas by condensation. The reaction is exothermic, generating high pressure steam. Energy consumption and steam production for the ammonia synthesis were assumed to be similar to those of a natural gas-based system [56, 57]. 
Nitric acid is produced by the exothermic reaction of ammonia and air over a catalyst and the absorption of the product gas in water. Half of the produced ammonia was assumed to be be converted to nitric acid. Data for yields, electricity use and steam production were taken from [58] and [59]. In the reaction, $\mathrm{N}_{2} \mathrm{O}$ is generated. However, using a combination of abatement techniques, the $\mathrm{N}_{2} \mathrm{O}$ emissions from a modern new built plant can be limited to between 0.12 and $0.6 \mathrm{~kg} \mathrm{~N}_{2} \mathrm{O} /$ ton nitric acid [58]. Here we assumed $0.6 \mathrm{~kg} /$ ton nitric acid (100\%), which recalculated can be expressed as $2.8 \mathrm{~g}$ $\mathrm{N}_{2} \mathrm{O} / \mathrm{kg} \mathrm{N}$.

By neutralising the nitric acid with the remainder of the ammonia, an ammonium nitrate solution is produced (exothermic reaction). The solution is evaporated to remove water. A modern plant produces enough heat in the neutralisation to remove the water and no additional heat is needed [60]. The ammonium nitrate is thereafter granulated. The electricity requirement is relatively small, $90 \mathrm{MJ} / \mathrm{ton}$ ammonium nitrate produced [61].

\section{Results and Discussion}

\subsection{Energy balance}

The calculated primary energy input and avoided primary energy use due to export of surplus heat and electricity are presented in Table 3. The results are presented as per ton $\mathrm{N}$ net output, i.e. after deduction of the use of some of the nitrogen in the biomass plantations.

There is no input of external energy to the production plants, the biomass serves both as raw material and energy source to drive the processes. In scenario 2 and 3, more energy is avoided than is put in. However in scenario 1, more energy is put in than avoided, mainly due to the assumption that the missing electricity is produced with coal power with low energy efficiency. Biomass input represents a large post. It can however also be interesting to study the fossil energy balance. In this case, the energy balance in that case gets even more favourable for scenario 1 and 2, with very low inputs and large avoided energy use. For scenario 1, there will however still be a net energy use.

\subsection{Land use}

The land use for Salix was calculated to be 0.22 ha per ton $N$ produced. This is the direct land use without any deductions for by-products.

Straw and forest residues do not require land for cultivation as they are by-products of other systems. However, to produce one ton of $\mathrm{N}$, straw needs to be collected from 0.5 ha cereal cultivation. For forest residues, the production of 1 ton $\mathrm{N}$ requires collection of residues from around 25 ha of felled forest. 
Table 3. Energy inputs and surplus energy to produce 1 ton $\mathrm{N}$ in the form of ammonium nitrate (after a certain amount of nitrogen has been returned to the biomass plantation).

\begin{tabular}{|c|c|c|c|c|}
\hline & $\begin{array}{l}1 \\
\text { (Forest residues } \\
- \text { integration in } \\
\text { existing CHP ) }\end{array}$ & $\begin{array}{l}2 \\
\text { (Straw - } \\
\text { new } \\
\text { thermal } \\
\text { gasificati } \\
\text { on plant) }\end{array}$ & $\begin{array}{l}3 \\
\text { (Salix - } \\
\text { new } \\
\text { thermal } \\
\text { gasifica } \\
\text { tion } \\
\text { plant) } \\
\end{array}$ & Unit \\
\hline Biomass input & 106 & 40 & 41 & GJ/ton $\mathrm{N}$ net \\
\hline Energy for cultivation, harvest and transport & 2 & 1 & 1 & $\mathrm{GJ} /$ ton $\mathrm{N}$ net \\
\hline Energy to replace missing electricity & 78 & -- & -- & $\mathrm{GJ} /$ ton $\mathrm{N}$ net \\
\hline Avoided energy due to electricity surplus & -- & 3 & 3 & $\mathrm{GJ} /$ ton $\mathrm{N}$ net \\
\hline Avoided energy due to heat surplus & 14 & -- & -- & GJ/ton $\mathrm{N}$ net \\
\hline $\begin{array}{l}\text { Avoided energy due to replacement of fossil } \\
\text { fertilisers }\end{array}$ & 53 & 53 & 53 & GJ/ton $\mathrm{N}$ net \\
\hline Sum (Inputs - Avoided) & 119 & -14 & -14 & $\mathrm{GJ} /$ ton $\mathrm{N}$ net \\
\hline
\end{tabular}

\subsection{Greenhouse gas emissions}

The GHG emissions per functional unit for the different scenarios are presented in Table 4. All the scenarios show a net reduction in GHG.

As explained in the previous section, the primary energy use is larger than the avoided energy use in the forest residue scenario. This is mainly due to the assumption that the missing electricity is replaced by coal power. However, the GHG emissions are reduced compared with the reference system. This is because the GHG emissions reduction is not only connected to energy use, but also to the nitrous oxide emissions from nitric acid production. In the reference system old technology was assumed, but in the renewable scenarios it was assumed that the plants were equipped with catalytic nitrous oxide removal filters. There is therefore a GHG saving in the forest residues scenario, even though the primary fossil energy use is higher.

In the thermal gasification scenarios (2 and 3) the main product is nitrogen and only small amount of surplus electricity is sold to the grid. The replacement of fossil $\mathrm{N}$-fertilisers dominates the results, so that the production only plays a minor role. 
Table 4. Emissions of greenhouse gases expressed as ton $\mathrm{CO}_{2}$-eq/ton $\mathrm{N}$, after deduction of internal requirements for biomass production

\begin{tabular}{|c|c|c|c|}
\hline & $\begin{array}{l}1 \\
\text { (Forest residues - } \\
\text { integration in } \\
\text { existing CHP ) }\end{array}$ & $\begin{array}{l}2 \\
\text { (Straw - new } \\
\text { thermal } \\
\text { gasification plant) }\end{array}$ & $\begin{array}{l}3 \\
\text { (Salix - new } \\
\text { thermal } \\
\text { gasification plant) }\end{array}$ \\
\hline Biomass production and transport & 0.2 & 0.1 & 0.2 \\
\hline Soil carbon emissions/uptake & 0.3 & 0.3 & -0.3 \\
\hline Nitric acid production & 0.4 & 0.4 & 0.4 \\
\hline Excess heat & -1.0 & 0.0 & 0.0 \\
\hline Excess electricity & -- & -0.2 & -0.2 \\
\hline Reduced electricity production & 4.8 & -- & -- \\
\hline Subtotal & 4.7 & 0.6 & 0.2 \\
\hline Replacement of fossil nitrogen & -7.3 & -7.3 & -7.3 \\
\hline Total & -2.6 & -6.7 & -7.1 \\
\hline
\end{tabular}

\subsection{Sensitivity analysis}

All modelling is associated with uncertainty. One way to examine the dynamics of a system is to test its sensitivity to changes in specific parameters or assumptions. The following sections describe sensitivity analysis for a number of selected parameters that have a large influence on the results.

Changing the functional unit to 1 hectare was tested for the scenarios studied, the results are presented in Table 5. For the functional unit 1 hectare, Salix thermal gasification scenario gave the largest reduction in GHG, since more nitrogen per hectare is produced than in the other scenarios. Contradictory, per functional unit ton $\mathrm{N}$, the results show no large difference between straw and Salix. For forest residues, there is almost no reduction at all in GHG emissions when expressed as per hectare; this is since the residues is divided over the forest rotation period giving a very low average annual yield. The decision on what is the most relevant functional unit can be discussed. Cherubini [62] e.g. recommends that LCA of bioenergy crops be expressed on a per hectare basis. In studies examining the best utilisation of 1 hectare of land for cultivation, it could be relevant to use this unit of comparison, as the difference between choices of crops could then be better assessed. In this study however the aim was to study the production of nitrogen, and we found that $1 \mathrm{~kg}$ nitrogen was the most relevant functional unit. The functional unit 1 hectare however gives further insight of the systems, which can be important for decision making.

When producing excess heat or electricity, in the base case it was assumed that fossil energy will be outcompeted on the energy market. However, there is also a chance that the less competitive renewable energy market will be affected. The results were tested assuming that the excess energy replaces other renewables (wind power and heat based on forest residues; data collected from Uppenberg et al. [25]. This has a certain influence on the results (Table 6); however there is still a net reduction in GHG emissions in scenario 2 and 3. For scenario 1, the missing electricity was in the base case assumed to 
be compensated for by fossil based electricity. If it is replaced by renewable electricity, the GHG savings will be much larger.

Table 5. Emissions of greenhouse gases expressed as ton $\mathrm{CO}_{2}$-eq/ha and year, after deduction of internal requirements for biomass production

\begin{tabular}{llll}
\hline & $\begin{array}{l}\mathbf{1} \\
\text { (Forest residues } \\
\text { - integration in } \\
\text { existing CHP })\end{array}$ & $\begin{array}{l}\mathbf{2} \text { (Straw - new } \\
\text { thermal } \\
\text { gasification } \\
\text { plant) }\end{array}$ & $\begin{array}{l}\mathbf{3} \text { (Salix - new } \\
\text { thermal } \\
\text { gasification } \\
\text { plant) }\end{array}$ \\
\hline Biomass production and transport & 0.01 & 0.11 & 0.91 \\
Soil carbon emissions/uptake & 0.01 & 0.55 & -1.23 \\
Nitric acid production & 0.02 & 0.76 & 1.86 \\
Excess heat & -0.04 & 0.00 & 0.00 \\
Excess electricity & 0.00 & -0.29 & -0.72 \\
Reduced electricity production & 0.19 & 0.00 & 0.00 \\
\hline Subtotal & 0.19 & 1.13 & 0.82 \\
\hline Replacement of fossil nitrogen & -0.29 & -13.6 & -33.4 \\
Total & -0.10 & -12.5 & -32.4 \\
\hline
\end{tabular}

An important factor in the GHG calculations is the reference system, as all savings are expressed relative to this. In the base case we assumed that the bio-based nitrogen would replace natural gasbased nitrogen with emissions of $7.3 \mathrm{~kg} \mathrm{CO}$-eq/ $\mathrm{kg} \mathrm{N}$. However, the emissions can vary depending on raw material, type of technology and age of the production plant (Table 6). In the sensitivity analysis, we tested the results of bio-based nitrogen replacing both a high emitting coal-based ammonia $(9.7 \mathrm{~kg}$ $\mathrm{CO}_{2}$-eq/kg $\left.\mathrm{N}\right)$ and low emitting natural gas-based ammonia produced in a modern plant $\left(2.8 \mathrm{~kg} \mathrm{CO}_{2^{-}}\right.$ eq $/ \mathrm{kg} \mathrm{N}$ ). The result is that in scenario 1, there will be no GHG saving, if the bio-nitrogen replaced low emitting fossil-based nitrogen.

When using biomass for new activities, emissions associated with loss or accumulation of carbon at the site of cultivation of the raw material can occur. This can be referred to as the direct land use change. In the base case it was assumed that harvesting straw would give a reduction of $150 \mathrm{~kg} \mathrm{C} / \mathrm{ha}$ and year. In the literature, however, the impact of straw removal varies greatly, from $385 \mathrm{~kg} \mathrm{C} / \mathrm{ha}$ and year carbon losses to having no significant impact at all (see section 2.3). The results were therefore tested for the range $0-385 \mathrm{~kg} \mathrm{C} / \mathrm{ha}$ and year. Salix was tested for values ranging between a loss of 1309 $\mathrm{kg} \mathrm{C} / \mathrm{ha}$ and year (planting on previous forest) and carbon accumulation of $1700 \mathrm{~kg} \mathrm{C} / \mathrm{ha}$ and year (planting on previous fallow land). Removing forest residues was tested for losses of between 3 and 50 $\mathrm{kg} \mathrm{C} / \mathrm{ha}$ and year. The results of the soil carbon sensitivity analysis are presented in Table 6 . As can be seen, soil carbon has an influence on the global warming results, especially in the Salix CHP scenario. 
Table 6. Reduction of GHG emissions (i.e. a large number is beneficial), for the base case and for a number of different sensitivity analysis scenarios. For each sensitivity analysis scenario, a minimum and maximum value for the changed parameter is used.

\begin{tabular}{|c|c|c|c|c|c|c|c|c|}
\hline \multirow[t]{2}{*}{ Scenario number } & \multicolumn{2}{|c|}{ Heat and electricity } & \multicolumn{2}{|c|}{$\begin{array}{l}\text { Replaced } \\
\text { nitrogen }\end{array}$} & \multicolumn{2}{|c|}{$\begin{array}{l}\text { Direct land } \\
\text { use change }\end{array}$} & \multicolumn{2}{|c|}{$\begin{array}{l}\text { Indirect land } \\
\text { use change }\end{array}$} \\
\hline & $\begin{array}{l}\text { Fossil (=base } \\
\text { case results) }\end{array}$ & $\begin{array}{l}\text { Renew- } \\
\text { able }\end{array}$ & Low & High & Low & High & Low & High \\
\hline $\begin{array}{l}1 \text { (Forest residues } \\
\text { - integration in } \\
\text { existing CHP ) }\end{array}$ & 2.6 & 5.9 & -1.9 & 5.0 & 1.6 & 2.8 & -- & -- \\
\hline $\begin{array}{l}2 \text { (Straw - new } \\
\text { thermal }\end{array}$ & & & & & & & & \\
\hline gasification plant) & 6.7 & 6.5 & 2.2 & 9.1 & 6.2 & 7.0 & -- & -- \\
\hline $\begin{array}{l}3 \text { (Salix - new } \\
\text { thermal }\end{array}$ & & & & & & & & \\
\hline gasification plant) & 7.1 & 7.0 & 2.6 & 9.5 & 5.8 & 8.2 & 3.3 & 6.7 \\
\hline
\end{tabular}

The assumption in the base case was that Salix plantation was placed on previously unused land and straw and forest residues collected from previously unutilised sites. However, there is a possibility that Salix will be planted on fields where other activities previously took place. Those activities will then be diverted to other locations, which can lead to emissions of GHG. Even if Salix is planted on previously unused land, the plantation itself prevents any other type of land use, for example expansion of crop production, and can therefore be argued to lead to indirect land use change (iLUC).

In recent years there has been an intensive debate on the indirect land use changes connected with the production of liquid biofuels. However, quantification of the indirect land use is very difficult and usually requires use of economic equilibrium models, which can predict the market response to an increased demand for biomass. It is not the case that 1 hectare of land use automatically leads to 1 hectare of land use elsewhere, since increased crop prices can lead to lower consumption and/or intensification of production. The models are very complex and the results are associated with high uncertainty. In a review study the figure was found to vary between -50 and $100 \mathrm{~g} \mathrm{CO}_{2}$-eq per MJ biofuel, with extremes up to $300 \mathrm{~g} \mathrm{CO}_{2}$-eq per $\mathrm{MJ}$ [63].

Here we tested the impact on the results in the Salix scenarios of assuming that the occupation of 1 hectare of land causes 1 hectare of crop cultivation elsewhere and a soil carbon loss connected to that hectare of either 10 ton $\mathrm{C} / \mathrm{ha}$ (low estimate) or 95 ton $\mathrm{C} / \mathrm{ha}$ (high estimate), according to the variation reported by Edwards et al. [64]. The soil carbon losses were divided over 20 years. Straw and forest residues were assumed to not cause any indirect land use. The results for the Salix scenario are presented In Table 6. It is clear that including iLUC has an effect on the results, but there is still a net saving of GHG compared with using fossil-based nitrogen. 


\subsection{Cost of production}

However important GHG reduction, the price competitiveness of green nitrogen will be decisive for commercial introduction. The average 2011 world market price for urea was 421 US dollars per ton [65], equivalent to around $6 \mathrm{SEK}$ per $\mathrm{kg} \mathrm{N}$. The ammonia price is related to the natural gas price, and subsequently also to the oil price [66]. Abram and Forster [67] report that natural gas feedstock makes up $90 \%$ of ammonia production costs. In this study, we did not make a cost calculation. However, in a study by Ahlgren et al. [68], the cost of producing ammonium nitrate based on electrolysis for hydrogen production in a large-scale biomass CHP was estimated to cost 8 SEK per kg N, slightly over the world market price for fossil-based fertilisers. Biomass feedstock represented a large cost, but also investment in plant equipment. However, as there is no biomass based nitrogen production at present the modelling was built on many assumptions, and the results are therefore connected to large uncertainties.

\subsection{Supply Swedish agriculture with green N?}

Around 167000 tons of fossil-based nitrogen in straight and compound fertilisers are used every year in Swedish agriculture [49]. In this study, 165 ton per day net nitrogen was assumed to be produced in each scenario. To supply Sweden with nitrogen, three such plants would be required.

In the straw scenario, around 7.2 PJ straw would be needed to produce all the green nitrogen required. In Sweden, it is estimated that $65 \%$ of the straw from cereal production is not harvested. All of it cannot be harvested, since it is needed to maintain good soil quality. The potential is further decreased due to weather and practical limitations. The straw potential taking these aspects into account is estimated to be 11-14 PJ per year [69].

For the Salix scenario, around 36600 ha of plantations would be needed to supply Sweden with green nitrogen. This can be compared against the total Salix area in Sweden at present, which is 13000 ha (equivalent to ca $0.5 \%$ of Swedens farmland).

Around 18 PJ per year of forest residues would be required to supply Sweden with nitrogen. The available statistics on forest residue harvesting are uncertain, but it is estimated that forest residues were harvested on 85000 ha (41\% of total final felling area) in 2008 [70]. The amount of forest residues per hectare varies between regions and types of stand, but using an average of $217 \mathrm{~kg}$ dry matter per hectare and year (see section 3.2) the harvested amount of forest residues in 2008 was equivalent to $28 \mathrm{PJ}$. Forest residues is today mainly utilised in industry and district heating for heat and power production [71]. Hence, there seems to be sufficient forest residues, and the potential to increase harvesting is large. 


\subsection{Using green fertilisers in crop production}

The emissions from rapeseed cultivation when using fossil based nitrogen $(7.3 \mathrm{~kg} \mathrm{CO}$-eq/kg N$)$ or the green nitrogen studied in this paper, are presented in Table 7. Data was collected from Bernesson [72] for everything except production of nitrogen fertilisers. The yield was assumed to be $2470 \mathrm{~kg} / \mathrm{ha}$ (8\% moisture content) and the amount of nitrogen fertiliser used $140 \mathrm{~kg} \mathrm{~N} / \mathrm{ha}$. It is evident that the use of green nitrogen can significantly lower the GHG emissions from cultivation of rapeseed.

Table 7. Greenhouse gas emissions from cultivation of rapeseed when using different types of nitrogen fertilisers, $\mathrm{g} \mathrm{CO}_{2}$-eq/kg rapeseed.

\begin{tabular}{lllll}
\hline & Type of N used & & \\
& Scenario & & $\mathbf{2}$ & (Straw - new \\
\cline { 2 - 5 } & & $\mathbf{3}$ & $\begin{array}{l}\text { (Salix - new } \\
\text { thermal } \\
\text { (hermal } \\
\text { gasification } \\
\text { plant) }\end{array}$ & $\begin{array}{l}\text { gasification } \\
\text { plant }\end{array}$ \\
\hline Seed & & & 3 & 3 \\
Production of P\&K fertilisers & 3 & 3 & 24 & 24 \\
Production of N fertilisers & 24 & 24 & 34 & 3 \\
Soil emissions & 413 & 266 & 329 & 329 \\
Production of pesticides & 329 & 329 & 2 & 2 \\
Tractive power & 2 & 2 & 72 & 72 \\
Heat for seed drying & 72 & 72 & 30 & 30 \\
Machinery inputs & 30 & 30 & 2 & 2 \\
Total emissions & 2 & 2 & 496 & 465 \\
Savings, \% of fossil case & 875 & 728 & $\mathbf{4 3 \%}$ & $\mathbf{4 6 \%}$ \\
\hline
\end{tabular}

\section{Conclusions}

The production of mineral nitrogen is one of the largest fossil energy inputs in Swedish agriculture. However, we have shown that mineral nitrogen can be produced based on renewable energy. This would lower the dependence on fossil energy in food production. The results showed that GHG emissions and use of fossil energy can be significantly lowered compared with fossil-based fertilisers, even when indirect land use changes are considered.

Using green nitrogen in crop production can substantially lower the energy and carbon footprint of crops. Using these crops for production of biofuels can also lower the carbon footprint of the biofuels, making the comparison to fossil fuels more favourable for biofuels.

It is however very difficult to draw general conclusions regarding choice of technology and raw material for production of green nitrogen, as results are highly dependent on the local context. Further, only energy balance and GHG emissions were assessed in the present study. The GHG emissions have 
lately been the dominant environmental impact in scientific studies, policy and regulation. However, many other environmental impacts can occur in a bioenergy system, such as eutrophication, acidification and impacts on biodiversity.

Food safety could be another impact that needs to be evaluated. Nitrogen is a vital component in maintaining high yields in crop production. We will sooner or later run out of fossil fuel. Without nitrogen fertilisers it will be difficult to feed and fuel a growing world population. We argue that of all the fossil energy we use, one of the first things we should replace is energy for nitrogen production. In that way we can secure future food, feed and bioenergy production. Production of nitrogen should in other words not be regarded as competing with other uses of renewables, but as a fundamental prerequisite for continued production of food and energy for a growing world population.

\section{Acknowledgements}

This project was carried out with financial support from Stiftelsen Lantbruksforskning - The Swedish Farmers' Foundation for Agricultural Research, to whom we express our thanks.

We would also like to thank Christian Hulteberg (CEO, Biofuel-Solution) and Klaus Noelker (Head of Process Department Ammonia and Urea Division, Udhe) for participation in the project. They provided input to the scenario construction and discussions and took the time to participate in a meeting in Uppsala.

\section{References}

1. Smil, V. Enriching the earth : Fritz Haber, Carl Bosch, and the transformation of world food production, Cambridge MIT Press, United States of America, 2001.

2. Smeets, E.; Faaij, A. Future Demand For Fertilizer From Bioenergy Crop Production. In: 73rd IFA Annual conference. Kuala Lumpur, Malaysia, 6-8 June 2005.

3. Erisman, J.W.; Sutton, M.A.; Galloway, J.; Klimont, Z.; Winiwarter, W. How a century of ammonia synthesis changed the world. Nature Geosci 2008, 1, 636-639.

4. IFA. Fertilizers, Climate Change and Enhancing Agricultural Productivity Sustainably. International Fertilizer Industry Association, First edition, Paris, France, 2009.

5. Ahlgren, S. Crop Production without Fossil Fuel. Production Systems for Tractor Fuel and Mineral Nitrogen Based on Biomass, Swedish University of Agricultural Sciences, Doctoral Thesis No 2009:78, Uppsala, Sweden, 2009.

6. SJV. Hur påverkar jordbruket klimatet? Swedish Board of Agriculture. http://www.jordbruksverket.se, 2008.

7. Börjesson, P.; Tufvesson, L.M. Agricultural crop-based biofuels - resource efficiency and environmental performance including direct land use changes. Journal of Cleaner Production 2011, 19, 108-120.

8. IFA. Energy Efficiency and $\mathrm{CO}_{2}$ Emissions in Ammonia Production 2008-2009 Summary Report. International Fertilizer Industry Association, 2009.

9. Otero, N.; Vitòria, L.; Soler, A.; Canals, A. Fertiliser characterisation: Major, trace and rare earth elements. Applied Geochemistry 2005, 20, 1473-1488. 
10. Chum, H.L.; Overend, R.P. Biomass and renewable fuels. Fuel Processing Technology 2001, 71, 187-195.

11. Ni, M.; Leung, D.Y.C.; Leung, M.K.H.; Sumathy, K. An overview of hydrogen production from biomass. Fuel Processing Technology 2006, 87, 461-472.

12. Burciaga, D. Clean Syngas for Drop-in Fuels: It starts in the gasifier. in Biomass 2011: Replace the Whole Barrel, Supply the Whole Market - The New Horizons of Bioenergy, July 26-27, 2011. National Harbor, Washington D.C, 2011.

13. Ahlgren, S.; Baky, A.; Bernesson, S.; Nordberg, A.; Norén, O.; Hansson, P.-A. Ammonium nitrate fertiliser production based on biomass - Environmental effects from a life cycle perspective. Bioresource Technology 2008, 99, 8034-8041.

14. Ahlgren, S.; Bernesson, S.; Nordberg, A.; Hansson, P.-A. Nitrogen fertiliser production based on biogas - Energy input, environmental impact and land use. Bioresource Technology 2010, 101, $7192-7195$.

15. UNIDO/IFDC. Fertilizer manual. Ed.: United Nations Industrial Development Organization (UNIDO), International Fertilizer Development Centre (IFDC), Kluwer Academic Publishers, United Staes of America, 1998.

16. Dubey, M. Technical and economic feasibility of making fertilizer from wind energy, water, and air. In: Sun, Mankind's future source of energy. Proceedings of the International Solar Energy Society Congress. New Delhi, India, January, 1978, 1812-1821.

17. Jourdan, J.; Roguenant, R. Small scale ammonia production as a means for hydrogen storage. In: Hydrogen energy system; Proceedings of the Second World Hydrogen Energy Conference, Zurich, Switzerland, August 21-24, 1978. Volume 3. (A80-23101 08-44) Oxford and New York, Pergamon Press, 1979, p. 1401-1429.

18. Grundt, T.; Christiansen, K. Hydrogen by water electrolysis as basis for small scale ammonia production. A comparison with hydrocarbon based technologies. International Journal Of Hydrogen Energy 1982, 7, 247-257.

19. Brainerd Dispatch. Ag \& Energy Expo explores producing fertilizer from wind http://brainerddispatch.com/news/2012-02-26/ag-energy-expo-explores-producing-fertilizer-wind Published 2012-02-26, 7:37 PM. 2012.

20. Baumann, H.; Tillman, A.-M. The Hitch Hiker's Guide to LCA. An orientation in life cycle assessment methodology and application 2004, Lund, Sweden: Studentlitteratur.

21. Kimming, M. Energy and greenhouse gas balance of decentralized energy supply systems based on organic agricultural biomass. A life cycle perspective. Licentiate thesis 028. Department of Energy and Technology, Swedish University of Agricultural Sciences, Uppsala, Sweden 2011.

22. Mathiesen, B.V.; Münster, M.; Fruergaard, T. Uncertainties related to the identification of the marginal energy technology in consequential life cycle assessments. Journal of Cleaner Production 2009, 17, 1331-1338.

23. Finnveden, G. A world with $\mathrm{CO} 2$ caps. The International Journal of Life Cycle Assessment 2008, $13,365-367$.

24. Levasseur, A.; Lesage, P.; Margni, M.; Desche nes, L.; Samson, R. Considering time in LCA: Dynamic LCA and its application to global warming impact assessments. Environmental Science \& Technology 2010, 44, 3169-3174. 
25. Uppenberg, S.; Alemark, M.; Lindfors, L.-G.; Marcus, H.-O.; Stripple, H.; Wachtmeister, A.; Zetterberg, L. Miljöfaktabok för bränslen. Del 2. Bakgrundsinformation och Teknisk bilaga. IVL Rapport B1334B-22001, Stockholm, Sweden, 2001

26. Cherubini, F. GHG balances of bioenergy systems - Overview of key steps in the production chain and methodological concerns. Renewable Energy 2010, 35, 1565-1573.

27. Energimyndigheten Energiläget i siffror. Energy in Sweden - Facts and figures. Report ET 2011:42, Swedish Energy Agency, 2011.

28. SOU Bioenergi från jordbruket - en växande resurs. Statens offentliga utredningar (SOU) 2007:36, Stockholm, Sweden, 2007.

29. Mubashir, V. Importance of Swedish Cogeneration Plants for the Domestic Energy System and the North European Power Exchange. Master of Science Thesis within the Sustainable Energy Systems Programme. Department of Energy and Environment, Division of Electric Power Engineering, Chalmers univerisity of technology, Gothenburg, Sweden, 2011.

30. EFMA Best Available Techniques for Pollution Prevention and Control in the European Fertilizer Industry. Production of Ammonia. Booklet No. 1, European Fertilizer Manufacturers Association, Brussels, Belgium, 2000.

31. Agrium Agrium's fertilizer industry. Factbook 2011-2012. http://www.agrium.com/includes/2011_Agrium_Fact_Book_v15_w_links.pdf, 2011.

32. Ahlgren, S.; Bernesson, S.; Baky, A.; Nordberg, Å.; Hansson, P.A. Green nitrogen- Possibilities for production of mineral nitrogen fertilisers based on renewable resources in Sweden, Report 030. Dep of Energy and Technology, Swedish University of Agricultural Sciences, Uppsala, Sweden, 2011.

33. Gustafsson, J.; Larsson, S.; Nordh, N.-E. Manual för Salixodlare, Lantmännen Agroenergi, Örebro, Sweden, 2007.

34. Phyllis Online database, composition of biomass and waste. http://www.ecn.nl/phyllis/ Energy research Centre of the Netherlands, 2012.

35. Gruvaeus, I.; Marmolin, C. Återföring av aska från bioenergigrödor odlade på åkermark, HS Skaraborg rapport nr 1/07, Skara, Sweden, 2007.

36. Bernesson, S.; Nilsson, D.; Hansson, P.A. A limited LCA comparing large- and small-scale production of rape methyl ester (RME) under Swedish conditions. Biomass \& Bioenergy 2004, 26, 545-559.

37. Bernesson, S.; Nilsson, D.; Hansson, P.A. A limited LCA comparing large- and small-scale production of ethanol for heavy engines under Swedish conditions. Biomass \& Bioenergy 2006, $30,46-57$.

38. Ahlgren, S.; Hansson, P.-A.; Kimming, M.; Aronsson, P.; Lundkvist, H. Greenhouse gas emissions from cultivation of agricultural crops for biofuels and production of biogas from manure - Implementation of the Directive of the European Parliament and of the Council on the promotion of the use of energy from renewable sources. Swedish University of Agricultural Sciences, Uppsala, Sweden, 2011.

39. Nilsson, D. Analysis and Simulation of Systems for Delivery of Fuel Straw to District heating Plants. Doctoral Thesis, Department of Agricultural Engineeering, Swedish University of Agricultural Sciences, Uppsala Sweden, 1999. 
40. Nilsson, D. Energy, exergy and emergy analysis of using straw as fuel in district heating plants. Biomass \& Bioenergy 1997, 13, 63-73.

41. Börjesson, P. Livscykelanalys av Salixproduktion. Lunds tekniska högskola. Institutionen för teknik och samhälle. Avdelningen för miljö- och energisystem. Rapport nr 60, Lund, Sweden, 2006.

42. RecAsh. Utbildningsmaterial-Grot PP. http://www.recash.info/uploads/documents/Grot1.pdf Downloaded 2009-02-03. 2009.

43. Lindholm, E.-L. Energy use and environmental impact of roundwood and forest fuel production in Sweden. Doctoral thesis. Acta Universitatis agriculturae Sueciae vol. 2010:40, Dept. of Energy and Technology, Swedish University of Agricultural Sciences, Uppsala, Sweden, 2010.

44. SCB. Utnyttjande av halm och blast från jordbruksgrödor 1997 - Utililazation of straw and tops from agriculture crops in 1997. Statistiska meddelanden Mi 63 SM 9901, Statistics Sweden, Stockholm, Sweden, 1999.

45. Johansson, W. Kolbindning och kolflöden vid odling. Sammanfattning aven analys rörande inverkan av växtföljdIodlingssystem och av restprodukttillförsel till marken. Rapport till Stiftelsen Lantbruksforkning. Institutionen för markvetenskap, Avdelningen för lantbrukets hydroteknik, Uppsala, Sweden, 1994.

46. Mattsson, L.; Larsson, H. Att föra bort eller bruka ner halmen påverkar mullhalt, daggmaskar och skadedjur. Undersökningar i långliggande försök $i$ Skåne. To remove or to incorporate straw affects organic matter, earthworms and pests. Studies in three long-term field experiments. Report no 210. Swedish University of Agricultural Sciences, Dept. of Soil Sciences, Division of Soil Fertility, 2005.

47. Röing, K.; Andren, O.; Mattsson, L. Long-term management effects on plant N uptake and topsoil carbon levels in Swedish long-term field experiments: cereals and ley, crop residue treatment and fertilizer N application. Acta Agriculturae Scandinavica Section B-Soil And Plant Science 2005, $55,16-22$.

48. Saffih-Hdadi, K.; Mary, B. Modeling consequences of straw residues export on soil organic carbon. Soil Biology and Biochemistry 2008, 40, 594-607.

49. SJV. Jordbruksstatistisk årsbok 2011 - Yearbook of agricultural statistics 2011. Jordbruksverket, Statistiska centralbyrån, Official Statistics of Sweden. 2011.

50. SJV. Kartläggning av mark som tagits ur produktion. Rapport 2008:7, Jordbruksverket, Swedish Board of Agriculture, 2008.

51. Nilsson, D. Transportation work and energy requirements for haulage of straw fuels - A comparison between the plants at Satenas and Svalov. Swedish Journal Of Agricultural Research 1995, 25, 137-141.

52. Overend, R.P. The average haul distance and transportation work factors for biomass delivered to a central plant. Biomass 1982, 2, 75-79.

53. Zeng, K.; Zhang, D. Recent progress in alkaline water electrolysis for hydrogen production and applications. Progress in Energy and Combustion Science 2010, 36, 307-326.

54. Hamelinck, C.; Faaij, A. Future prospects for production of methanol and hydrogen from biomass. Journal of Power Sources 2002, 111, 1-22. 
55. Edwards, R.; Larivé, J.-F.; Mahieu, V.; Rouveirolles, P. Well-to-Wheels analysis of future automotive fuels and powertrains in the European context. CONCAWE \& EUCAR for the Joint Research Centre, Ispra, Italy, 2007.

56. Dybkjær, I. New Reforming Concepts for Large Scale $\mathrm{NH}_{3}$ Plants. In: 50th Annual Safety in Ammonia Plants and Related Facilities Symposium 2005. September 25-29 2005, Ontario, Canada, 2005.

57. Udhe

Ammonia.

http://www.uhde.eu/cgibin/byteserver.pl/archive/upload/uhde_brochures_pdf_en_5.00.pdf Downloaded 2011-08-05, 2011.

58. IPPC. Reference Document on Best Available Techniques for the Manufacture of Large Volume Inorganic Chemicals - Ammonia, Acids and Fertilisers. BREF 08.07. Integrated Pollution Prevention and Control, under the European Commission, 2007.

59. Saigne, M. Energy Balance in an Ammonium Nitrate-Nitric Acid Plant. in Proceedings No. 338. International Fertiliser Society, York, UK. . 1993.

60. Jenssen, T.; Kongshaug, G. Energy consumption and greenhouse gas emissions in fertiliser production. In: Proceedings No. 509. International Fertiliser Society, York, UK, 2003.

61. EFMA. Best Available Techniques for Pollution Prevention and Control in the European Fertilizer Industry. Production of Ammonium Nitrate and Calcium Ammonium Nitrate. Booklet No. 6, European Fertilizer Manufacturers Association, Brussels, Belgium, 2000.

62. Cherubini, F.; Bird, N.D.; Cowie, A.; Jungmeier, G.; Schlamadinger, B.; Woess-Gallasch, S. Energy- and greenhouse gas-based LCA of biofuel and bioenergy systems: Key issues, ranges and recommendations. Resources, Conservation and Recycling 2009, 53, 434-447.

63. Ahlgren, S.; Börjesson, P. Indirekt förändrad markanvändning och biodrivmedel - en kunskapsöversikt. Rapport 73. Juni 2011. Lunds universitet, Lunds Tekniska Högskola, avd för miljö-och energisystem, Lund, Sweden, 2011.

64. Edwards, R.; Mulligan, D.; Marelli, L. Indirect Land Use Change from increased biofuels demand. Comparison of models and results for marginal biofuels production from different feedstocks. JRC Scientific and Technical Reports, EUR 24485 EN - 2010, Ispra, Italy, 2010.

65. World Bank Commodity data July 2012. http://siteresources.worldbank.org/INTPROSPECTS/Resources/334934-1111002388669/8293921325803576657/Pnk_0712.pdf, 2012.

66. Pettersen, I.; Hval, J.N.; Vasaasen, A.; Alnes, P.K. Globalt marked med nasjonale sarpreg Utredning om konkurransen $i$ de nordiske mineralgjødselmarkeder, O. Norsk institutt for landbruksøkonomisk forskning (NILF), Norway, 2010.

67. Abram, A.; Forster, D.L. A primer on ammonia, nitrogen fertilizers, and natural gas markets. Report AEDE-RP-0053-05. Department of AED EconomicsThe Ohio State University, United States of America, 2005.

68. Ahlgren, S.; Bernesson, S.; Baky, A.; Nordberg, Å.; Hansson, P.A. Mineral nitrogen fertilisers produced from biomass - technical solutions and emission reduction possibilities. In: 19th European Biomass Conference and Exhibition. 6-10 June, Berlin, Germany, 2011.

69. Nilsson, D.; Bernesson, S. Halm som bränsle - Del 1: Tillgångar och skördetidpunkter. Institutionen för energi och teknik Rapport 011, Sweish University of Agricultural Sciences, Uppsala, Sweden, 2009. 
70. Skogsforsk (the Forestry Research Institute of Sweden) Skogsbränsle - tillgångar och utnyttjande $i$ Sverige. http://www.skogforsk.se/sv/KunskapDirekt/skogsbransle/Energi-fran-skog/Har-finnsskogsbranslet/Uttag-av-skogsbransle-i-Sverige/ . Accessed 2012-10-22, 2012.

71. Energiaskor. GROT-uttag och askåterföring - tillvägagångssätt, rekommendationer, effekter. Skogsstyrelsen Västra Götaland, RecAsh och Life. http://www.energiaskor.se/pdf-dokument/aska till skog och mark/GROT.pdf Downloaded 2011-08-09, 2011.

72. Bernesson, S. Life Cycle Assessment of Rapeseed Oil, Rape Methyl Ester and Ethanol as Fuels - A Comparison Between Large-And Small-Scale Production. Miljö, teknik och lantbruk, Rapport 2004:01. Department of Biometry and Engineering, Swedish University of Agricultural Sciences, Uppsala, Sweden., 2004.

(C) 2012 by the authors; licensee Insciences Journal.

Open Access article under the terms and conditions of Creative Commons Attribution Non-Commercial License 3.0 Unported. 